\title{
The Reign of James VI and I
}

Each volume in the 'Problems in Focus' series is designed to make available to students important new work on key historical problems and periods that they encounter in their courses. Every volume is devoted to a central topic or theme, and the most important aspects of this are dealt with by specially commissioned essays from authorities in the relevant fields. The editorial Introduction reviews the problem or period as a whole, and each essay provides an assessment of the particular aspect, pointing out the areas of development and controversy, and indicating where conclusions can be drawn or where further work is necessary. An annotated bibliography serves as a guide to further reading. 


\section{PROBLEMS IN FOCUS SERIES}

\section{TITLES IN PRINT}

Church and Society in England: Henry VIII to James I edited by Felicity Heal and Rosemary O'Day

The Reign of James VI and I edited by Alan G. R. Smith The Origins of the English Civil War edited by Conrad Russell

The Interregnum: The Quest for Settlement 1646-1660 edited by G. E. Aylmer

The Restored Monarchy 1660-1688 edited by J. R. Jones Britain after the Glorious Revolution 1689-1714 edited by Geoffrey Holmes

Popular Movements, c. 1830-1850 edited by J. T. Ward The New Poor Law in the Nineteenth Century edited by Derek Fraser Britain Pre-eminent: Studies of British World Influence in the Nineteenth Century edited by C. J. Bartlett Perspectives in English Urban History edited by Alan Everitt Sweden's Age of Greatness 1632-1718 edited by Michael M. Roberts The Republic and the Civil War in Spain edited by Raymond Carr Europe's Balance of Power 1815-1848 edited by Alan Sked The Edwardian Age: The Search for Order 1900-1914 edited by Alan O'Day

The Mid-Tudor Polity c. 1540-1560 edited by Jennifer Loach and Robert Tittler Slavery and British Society 1776-1846 edited by James Walvin Reactions to the English Civil War 1642-1649 edited by John Morrill FURTHER TITLES ARE IN PREPARATION 


\section{The Reign of \\ James VI and I}

EDITED BY

ALAN G. R. SMITH

$\mathbf{M}$ 
(C) Alan G. R. Smith, Jennifer M. Brown, Gordon Donaldson, S. G. E. Lythe, Christina Larner, John Bossy, Brian Dietz, Louis B. Wright, Menna Prestwich, W. J. Jones, G. C. F. Forster 1973

All rights reserved. No part of this publication may be reproduced or transmitted, in any form or by any means, without permission.

First edition 1973

Reprinted 1977, 1979, 1981, 1983

Published by

THE MACMILLAN PRESS LTD

London and Basingstoke Associated companies in Delhi Dublin

Hong Kong fohannesburg Lagos Melbourne

New York Singapore and Tokyo

ISBN 978-0-333-12162-7 ISBN 978-1-349-15500-2 (eBook)

DOI 10.1007/978-1-349-15500-2

The paperback edition of this book is sold subject to the condition that it shall not, by way of trade or otherwise, be lent, re-sold, hired out, or otherwise circulated without the publisher's prior consent in any form of binding or cover other than that in which it is published and without a similar condition including this condition being imposed on the subsequent purchaser. 


\section{Contents}

Preface

Introduction

vii

ALAN G. R. SMITH

I Scottish Politics 1567-1625

22

JENNIFER M. BROWN

2 The Scottish Church 1567-1625

GORDON DONALDSON

3 The Economy of Scotland under James VI and I

S. G. E. LYTHE

4 James VI and I and Witchcraft

CHRISTINA LARNER

5 The English Catholic Community 1603-1625

JOHN BOSSY

6 England's Overseas Trade in the Reign of James I 106 BRIAN DIETZ

7 Colonial Developments in the Reign of James I

LOUIS B. WRIGHT

8 English Politics and Administration 1603-1625

140 MENNA PRESTWICH

9 Constitutional Ideas and Parliamentary Developments in England 1603-1625

ALAN G. R. SMITH

10 The Crown and the Courts in England 1603-1625

W. J. JONES

I The English Local Community and Local Government 1603-1625

G. C. F. FORSTER

List of Abbreviations

Bibliography

Notes and References

226

Notes on Contributors

246

Index 


\section{Preface}

THERE are obvious omissions in this book of essays on the reign of James VI and I, most notably, perhaps, articles on the Jacobean Church of England, on the English economy as a whole, and on foreign policy. It was originally hoped to secure contributions on each of these subjects, but it proved impossible to do so within a reasonable time limit. I have tried to compensate to some extent for the lacunae in my introduction. A valuable outline of religious policy in James I's reign in England is given by Dr Nicholas Tyacke in his chapter 'Puritanism, Arminianism and Counter-Revolution' in Conrad Russell (ed.), The Origins of the English Civil War (1973).

The spelling and punctuation of quotations have been modernised, though this was done with reluctance in the Scottish chapters, where the loss of the flavour of the original is much regretted. Place of publication is given for all books cited in the Bibliography. In the References and Notes the place of publication is London unless otherwise stated. (This does not apply to periodicals and works issued by historical clubs and societies, where the place of publication is never given.)

I would like to thank my contributors for their co-operation; it was a pleasure to work with them. We all hope that our volume will prove useful to students of history who are interested in the reign of the monarch who united the Crowns of Scotland and England. Finally I owe a personal debt to Miss Patricia Ferguson, who typed both the Introduction and chapter 9 in her usual immaculate way. 